\title{
Idiopathic Sudden Hearing Loss: Relationship with Stress Perception, Coping Styles, Temperament and Personality Traits
}

\author{
Idiopatik Ani Iş̧itme Kaybı: Stres Algısı, Baş Etme Stilleri ve Mizaç ve Kişilik \\ Özellikleri ile Illişkisi
}

\author{
Arzu Karaman Koç ${ }^{1 \oplus}$, Fatma Akyüz Karacan ${ }^{2} \oplus$ \\ ${ }^{1}$ Bakırköy Dr. Sadi Konuk Education and Research Hospital Ent Clinic, Istanbul, Turkey \\ ${ }^{2}$ Bakırköy Dr. Sadi Konuk Education and Research Hospital Psychiatry Clinic, İstanbul, Turkey
}

Received: 11 February 2020 / Accepted: 20 February 2020 / Publication date: 26 March 2020

Cite as: Karaman Koç A, Akyüz Karacan F. Idiopathic sudden hearing loss: Relationship with stress perception, coping styles, temperament and personality traits. Med J Bakirkoy 2020;16(1):90-4.

\begin{abstract}
Objective: Literature knowledge about the etiology of idiopathic sudden sensorineural hearing loss (ISSHL) is limited. In many cases any cause cannot be demonstrated and the disease is termed as idiopathic. We aimed to compare the sudden hearing loss patients with healthy controls, in terms of their stress perception, coping styles and temperament and character traits. We hypothesized that ISSHL patients have higher stress levels and they are more sensitive to stressfull conditions.

Method: The study was conducted with a total of 94 participants, consisting of 44 patients with a diagnosis of sudden sensorineural hearing loss and 50 healthy controls. Any participant with a psychiatric disease, history of medical treatment for psychiatric or organic brain disorder were excluded from the study. All participants were evaluated by self reports of The Perceived Stress Scale, Coping Inventory, for Stressful Situations Temperament and Character Inventory (TC) applied to the patients on the day of their hospitalization.

Results: Compaired to healty controls, patients with ISSHL had higher perceived stress scores, lower harm avoidance scores and higher reward dependence scores when compaired to controls. The ways of coping with stres were not different in-between the patients with sudden hearing loss and healthy controls. Moreover there was no correlation between the perceived stress levels and temperament and personality traits in groups.

Conclusion: In the present study, ISSHL patients had higher stress levels, lower harm avoidance, and higher reward dependence scores compaired to controls. These findings point out the importance of psychosocial factors in the etiology of ISSHL. ISSHL patients should be evaluated together with consultation-liaison psychiatry outpatient clinic, character, temperament characteristics and stress perception should be taken into conside.
\end{abstract}

Keywords: Idiopathic sudden sensorineural hearing loss, stress perception, coping styles, temperament and character

öz

Amaç: Idiyopatik ani sensorinöral işitme kaybının (ISSHL) etiyolojisi hakkında literatür bilgisi sınırlıdır. Birçok durumda herhangi bir neden gösterilemez ve hastalık idiyopatik olarak adlandırılır. Bu çalışmada ISSHL hastalarının, stres algıları, başa çıkma stilleri, mizaç ve kişilik özellikleri sağlıklı kontrollerle karşılaştırıldı. ISSHL hastalarının stres düzeylerinin daha yüksek olduğu ve stres koşullarına daha duyarlı oldukları varsayıldı.

Yöntem: Çalışma, 44’ü ISSHL tanısı alan ve 50'si sağlıklı kontrol olmak üzere toplam 94 katılımcı ile gerçekleştirildi. Psikiyatrik bir hastalığı olan, psikiyatrik veya organik beyin hastalığına yönelik tıbbi tedavi öyküsü olan hastalar çalışma dışı bırakıldı. Tüm katılımcılar, hastaneye yatış günün de Algılanan Stres Ölçeği, Başa Çıkma Envanteri, Mizaç ve Karakter Envanteri ile değerlendirildi.

Bulgular: Kontrol gurubu ile karşılaştırıldığında, ISSHL olan hastalarda, algılanan stres puanları ve zarardan kaçınma puanları düşük ve ödül bağımlılık puanları ise daha yüksek bulundu. Stresle başa çıkma yolları açısından ISSHL hastaları ve sağıklı kontroller arasında anlamlı farklılık bulunmadı. Ayrıca algılanan stres düzeyleri ile mizaç ve kişilik özellikleri açısından gruplar arasında bir ilişki bulunamamıştır.

Sonuç: Bu çalışmada, ISSHL hastalarının, stres düzeyleri daha yüksek, zarardan kaçınma skorları daha düşük ve kontrollerle karşılaştırıldığında ödül bağımlılık skorları daha yüksek olarak bulundu. Bu bulgular ISSHL etiyolojisinde psikososyal faktörlerin önemine işaret etmektedir. ISSHL hastaları konsültasyon-liyezon psikiyatrisi polikliniği ile birlikte değerlendirilmeli, karakter, mizaç özellikleri ve stres algısı dikkate alınmalıdır.

Anahtar kelimeler: Idiopatik ani sensörinöral işitme kaybı, stres algısı, başa çıkma stilleri, mizaç ve karakter

Corresponding Author:

karamankocarzu@yahoo.com
A. Karaman Koç 0000-0002-2496-3333

F. Akyüz Karacan 0000-0001-6166-9355

(C) Telif hakkı Sağlık Bilimleri Üniversitesi Bakırköy Dr. Sadi Konuk Eğitim ve Araştırma Hastanesi'ne aittir. Logos Tıp Yayıncılık tarafindan yayınlanmaktadır. Bu dergide yayınlanan bütün makaleler Creative Commons Atff-GayriTicari 4.0 Uluslararası Lisansı ile lisanslanmıştır.

(c) Copyright Health Sciences University Bakırköy Sadi Konuk Training and Research Hospital. This journal published by Logos Medical Publishing.

Licenced by Creative Commons Attribution-NonCommercial 4.0 International (CC BY-NC 4.0) 


\section{INTRODUCTION}

Idiopathic Sudden Sensorineural Hearing Loss (ISSHL) is characterized by the development of at least $30 \mathrm{~dB}$ hearing loss in 3 consecutive audiometric frequencies measured within less than three days ${ }^{(1)}$. Vestibular symptoms, tinnitus, and fullness in the effected ear can accompany the hearing loss ${ }^{(2)}$. ISSHL can affect patients with any age however the incidence peaks between $43-53$ years of age ${ }^{(3)}$. The disease is slightly more common in males ${ }^{(4)}$.

Etiological factors can be determined in only $7 \%$ to $45 \%$ of ISSHL patients and the disease is termed as idiopathic in vast majority of cases ${ }^{(2)}$. Its pathophysiological mechanisms may include not only viral infections, tumor and immune system dysfunction but also pyschological stress and vascular events can be the etiological factors ${ }^{(3)}$. Cochlea has an increased risk for damage due to hypoxia or ischemia because of it is an end organ in terms of vascularisation. Kropp \& Rad suggested that acute or chronic psychological stress may cause increased intravascular hemoconcentration in the cochlear artery and cause hypoxia or ischemia.

Stress is the effort that an individual exerts beyond his/her physical and psychological boundaries due to disturbing conditions in surrounding physical and social environment ${ }^{(5)}$. Stress stimulates the sympathic nervous system and hypothalamo-pituitaryadrenal axis. Allostatic load effects many types of tissues and organs and leads to neuronal atrophy, immune deficiency and atherosclerosis. Thus high level of stress causes negative consequences such as worsening of well-being, reducing and compelling the capacity of the person ${ }^{\left({ }^{6}\right)}$. The stress level of an individual relates to the characteristics of stressful condition and also specific features of the individual. The specific features are stress perception, coping styles and personality traits. Each individual may perceive different levels of stress and use different ways of coping in a particular stressful situation. Coping with stress is defined as behavioral and mental effort that focus on controlling external or internal reactions or conflicts in between them with the purpose of decreasing the perceived threat and the resulting damage ${ }^{(5,7)}$.
Personality is another feature which determines the person's response to stress. Personality directly effects stress perception level of the individual. Different kind of personality classifications have been performed. Cloninger et al, distinguish between seven personality traits within the domains of temperament (Novelty Seeking, Harm Avoidance, Reward Dependence, Persistence), and character (Self-Directedness, Cooperativeness, SelfTranscendence) ${ }^{(8,9)}$. Importance of knowing personality, temperament and character specialities in the pathophysiology and prognosis of the diseases has been reported.

Schüssler et al. showed that disease prognosis was positively influenced by tendency towards negative dependency and balanced emotional personality traits in patients with ISSHL ${ }^{(10)}$. In another study, it was observed that ISSHL patients had emotional instability and aggressive personality traits ${ }^{(11)}$. In addition, ISSHL has been shown to be associated with sensuality, guilt, and repressed seizures ${ }^{(12)}$.

However, according to the English-language literature there is lack of knowledge about the etiology of ISSHL. In the present study we aimed to investigate the relationship between stress perception, coping skills and personality traits with ISSHL.

\section{MATERIALS and METHODS}

\section{Participant and Treatment Protocol}

The charts of 94 patients were evaluated retrospectively. Perceived Stress Scale, Ways of Coping Inventory, Temperament and Character Inventory tests were applied to a total of 44 patients who were admitted to the Ear Nose Throat Clinic in Bakırköy Dr Sadi Konuk Training and Research Hospital with sudden hearing loss and diagnosed as ISSHL. Patients with a psychiatric disease, history of medical treatment for psychiatric or organic brain disorder were excluded from the study. The control group consisted of 50 healthy participants who were subjected to Perceived Stress Scale, Ways of Coping Inventory, Temperament and Character Inventory tests

\section{Statistical Analysis}

Number Cruncher Statistical System (NCSS) 2007 (Kaysville, Utah, USA) program was used for statistical 
Table 1. Distribution of descriptive features.

\begin{tabular}{ccccc}
\hline & $\begin{array}{c}\text { Total } \\
(\mathbf{n}=94)\end{array}$ & $\begin{array}{c}\text { Patient Group } \\
(\mathbf{n}=44)\end{array}$ & $\begin{array}{c}\text { Control Group } \\
(\mathbf{n}=50)\end{array}$ & P \\
\hline Age; mean \pm SD & $38,19 \pm 9,51$ & $38,77 \pm 9,74$ & $37,68 \pm 9,47$ & ${ }^{\mathrm{a}} 0,699$ \\
\hline $\begin{array}{c}\text { Gender: } \mathrm{n}(\%) \\
\text { Male }\end{array}$ & $38(40,4)$ & $18(40,9)$ & $20(40)$ & ${ }^{\mathrm{b}} 0,949$ \\
Female & $56(59,6)$ & $26(59,1)$ & $30(60)$ & \\
\hline
\end{tabular}

${ }^{a}$ Independent Samples test (Student $t$ test)

${ }^{b}$ Ki-Square test

analysis. Independent Samples t-test (Student t test) was used as descriptive statistical methods (mean, standard deviation, median, frequency and ratio), and for the correlation analysis of normally distributed variables in groups. Pearson's chi-Square test was used to compare qualitative data. Significance was evaluated at $p<0.05$.

\section{RESULTS}

Patient and control groups consisted of 94 participants. The mean age of participants was $39.19 \pm 9.51$ (22-25) years. Thirty -eight $(40.4 \%)$ cases were male; and fifty-six (59.6\%) were women. Distribution of descriptive features is presented in Table 1 . The groups were similar in terms of age and sex of the participants ( $p>0.05)$.

There were not any statistically significant differen-
Table 4. Distribution of Perceived Stress Scale scores in groups.

\begin{tabular}{llcc}
\hline & \multicolumn{2}{l}{ Perceived Stress Score } & \\
\cline { 2 - 3 } & Mean & SD & P \\
\hline Patient Group & 30,95 & 8,62 & $0,001^{* *}$ \\
Control Group & 23,08 & 3,10 & \\
\hline Total & 26,77 & 7,39 & \\
\hline
\end{tabular}

Independent Samples test (Student $t$ test)

${ }^{* *} p<0,01$

ces between groups according to scores of novelty seeking (NS), persistence, self-directedness (SD), cooperativeness and self-transcendence (ST) in temperament and personality inventory $(p>0.05)$. The patient group had statistically significantly lower Harm Avoidance (HA) and statistically significantly higher Reward Dependence (RD) scores than the control group $(p<0.01)$. Distribution of the scores of subdimensions of temperament and character inventory are shown in Table 2.

There were no statistically significantly differences between the patient and control groups according to the scores of problem solving, social support and avoidance subscale scores of $\mathrm{WCl}(p>0.05)$ (Table 3$)$.

Perceived stress scores were found to be statistically significantly higher in the patient group than the control group $(p<0.01)$ (Table 4$)$.

Table 2. Distribution of the scores of sub-dimensions of temperament and character inventory.

\begin{tabular}{|c|c|c|c|c|}
\hline Temperament and Character Invantory & $\begin{array}{c}\text { Total } \\
\text { Mean } \pm S D\end{array}$ & $\begin{array}{c}\text { Patient Group } \\
\text { Mean } \pm S D\end{array}$ & $\begin{array}{l}\text { Control Group } \\
\text { Mean } \pm S D\end{array}$ & $\mathbf{P}$ \\
\hline Novelty Seeking & $15,87 \pm 3,88$ & $15,41 \pm 4,08$ & $16,28 \pm 3,74$ & 0,449 \\
\hline Harm Avoidance & $20,51 \pm 5,19$ & $17,77 \pm 6,09$ & $22,92 \pm 2,50$ & $0,001 * *$ \\
\hline Reward Dependence & $15,66 \pm 3,20$ & $17,32 \pm 3,64$ & $14,20 \pm 1,80$ & $0,001 * *$ \\
\hline Persistence & $4,77 \pm 1,61$ & $4,55 \pm 1,54$ & $4,96 \pm 1,67$ & 0,383 \\
\hline Self directedness & $24,38 \pm 7,03$ & $25,68 \pm 6,07$ & $23,24 \pm 7,72$ & 0,239 \\
\hline Cooperativeness & $26,70 \pm 5,23$ & $25,82 \pm 7,14$ & $27,48 \pm 2,54$ & 0,310 \\
\hline Self-Transcendence & $19,57 \pm 4,84$ & $19,32 \pm 5,87$ & $19,80 \pm 3,84$ & 0,738 \\
\hline
\end{tabular}

Independent Samples test (Student $t$ test), ${ }^{* *} p<0,01$

Table 2. Distribution of the scores of sub-dimensions of temperament and character inventory.

\begin{tabular}{|c|c|c|c|c|}
\hline Stress-Coping Style Inventory Subscales & $\begin{array}{c}\text { Total } \\
\text { Mean } \pm S D\end{array}$ & $\begin{array}{c}\text { Patient Group } \\
\text { Mean } \pm S D\end{array}$ & $\begin{array}{c}\text { Control Group } \\
\text { Mean } \pm S D\end{array}$ & $\mathbf{P}$ \\
\hline Problem Solving & $19,96 \pm 4,12$ & $20 \pm 3,95$ & $19,92 \pm 4,35$ & 0,948 \\
\hline Social Support & $18,51 \pm 4,27$ & $18,32 \pm 4,01$ & $18,68 \pm 4,57$ & 0,776 \\
\hline Avoidance & $20,57 \pm 4,30$ & $20,55 \pm 4,83$ & $20,60 \pm 3,88$ & 0,966 \\
\hline
\end{tabular}

Independent Samples test (Student $t$ test), ${ }^{* *} p<0,01$ 


\section{DISCUSSION}

In the present study, we aimed to compare ISSHL patients with healthy controls according to their stress perception, ways of coping mechanisms, temperament and character traits. We found that ISSHL patients had higher perceived stress scores, lower harm avoidance scores and higher reward dependence scores than the control group.The ways of coping with stress were not different between the ISSLH patients and healthy controls. Furthermore there was no correlation between the perceived stress levels and temperament and personality traits in two groups.

Miguel et al. (2009) suggested that stress causes vasoconstriction, hyperviscosity and platelet aggregation in the labyrinthine artery, inner ear hypoxia or ischemia ${ }^{(13)}$. In ISSHL, patients reported higher stress levels and more stressful life-events before the sudden hearing loss occurred when comparied with healthy controls. While certain single-case studies have reported the association between stress and ISSHL which used qualitative interviews as assessment instruments ${ }^{(14-16)}$. However, any standardized assesment methods were not found, and quantitative statistical analysis of the collected data was not performed Two other studies, which limited by method and design, had similar results ${ }^{(14,16)}$. Consistent with these previous researches in our study, the results showed that patients with ISSHL have significantly higher levels of perceived stress scores compaired with the control group.

However the disease is termed as idiopathic. Many factors have been stated in the etiology of ISSHL. Yamasoba et al. (1993) reported that insufficiency of the vertebrobasilar system can cause sudden hearing loss ${ }^{(17)}$. Suckfüll et al. found higher plasma fibrinogen ratio in ISSHL patients which indicates the increased coagulability ${ }^{(18)}$. In $3 \%$ of ISSHL patients vascular or hematologic pathologies were causative factors ${ }^{(19)}$. Psychological stress is an important factor in vascular pathologies. It stimulates the sympathetic nervous system and the hypothalamic-pituitaryadrenal axis and causes vasoconstriction in visceral organs and reduces tissue perfusion ${ }^{(20)}$. Psychological stressors, depression and anxiety have been shown to cause severe hypercoagulability in patients with atherosclerosis ${ }^{(21)}$.
Coping mechanisms are important in determining how the individual experiences the stress in a specific stressful situation. In other words the ways of coping with stress are important for psychiatric and physiological outcomes of stress on our body. The negative effects of stress are directly related to the coping behavior. It was reported that the ability of using effective coping strategies has protective effects on the individual health ${ }^{(7)}$.

There are similarities in the pathophysiology of acute myocardial infarction and ISSHL. In our study, reward dependence (RD) scores were found to be higher in the patient group than in the control group. Similar to our study, In a study RD scores were found to be higher in patient with acute $\mathrm{MI}$ than in control group ${ }^{(22)}$. The patients with higher RD scores are defined as having tendency to be affectionate, warm, sensitive, dependent and social. They seek a social relationship and are open to communicate with others. Although capable of warm social relationships is one of the most important advantage of people with high RD, these people has an important disadvantage; their opinions and emotions can be easily influenced by others. Efforts to please the other people is a major burden on these people who have higher reward dependence levels ${ }^{(22,23)}$.

Harm avoidance scores were found to be higher in patients who had psychosomatic disease, chronic pain, irritable bowel syndrome or tinnitus. Increased harm avoidance scores are related to careful planning and high cautiousness in the event of danger $(23,24)$. In our study, the harm avoidance scores were found to be lower in ISSHL patients than the control group. The people with lower harm avoidance scores are confident, relaxed, courageous, energetic, sympathetic, optimistic even in situations that concern most people. It was thought that lower harm avoidance scores could be related to the possibility of danger or stress situation that cannot be predicted and higher perception of stress in stressful life events ${ }^{(23,25)}$. Studies have shown that patients with ISSHL have a higher level of emotional instability, aggressive personality traits, and repressed guilt associated with very severe attacks of anger ${ }^{(11,12)}$.

Schüssler et al. suggested that; while psychosocial factors may have an affect on the onset of ISSHL, 
there is a positive effect of balanced emotional personality, good friendship and reduction of stress factors on the prognosis of the disease and the prognosis is worser in patients with a tendency to addiction ${ }^{(10)}$. Personality traits may exert an important role on the occurrence and prognosis of the disease (26). ISSHL patients should be evaluated together with consultation-laison psychiatry outpatient clinic and the patients must be evaluated in terms of character, temperament characteristics and stress perception.

In conclusion we found that ISSHL patients had higher stress levels, lower harm avoidance and higher reward dependence scores compaired to the control group. These findings point out the importance of psychosocial factors in ISSHL etiology. Consideration of psychosocial factors in a case -spesific approach may contribute to the understanding of the pathophysiology, prognosis and also treatment of the disease. We suggest that the treatment of ISSHL patients should be done in a multidiciplinary approach.

Ethics Committee Approval: Bakırköy Dr. Sadi Konuk and Research Hospital Clinical Research Ethics Committee approval was received (2020/65).

Conflict of Interest: None

Funding: None

Informed Consent: Informed consent was obtained from all individual participants included in the study.

\section{REFERENCES}

1. Wilson WR, Byl FM, Laird N. The efficacy of steroids in the treatment of idiopathic sudden hearing lossa double-blind clinical study. Arch Otolaryngol. 1980;106(12):772-6. https://doi.org/10.1001/archotol.1980.00790360050013

2. Lazarini PR, Camargo AC. Idiopathic sudden sensorineural hearing loss: Etiopathogenic aspects. Braz J Otorhinolaryngol. 2006;72(4):554-61. https://doi.org/10.1016/S1808-8694(15)31004-1

3. Kaya H, Karaman Koç A, Sayın i, et al. Vitamins A, C, and E and selenium in the treatment of idiopathic sudden sensorineural hearing loss. Eur Arch Otorhinolaryngol. 2015;272(5):1119-25. https://doi.org/10.1007/s00405-014-2922-9

4. Wu CS, Lin HC, Chao PZ. Sudden sensorineural hearing loss: Evidence from Taiwan. Audiol Neurootol. 2006;11(3):151-6. https://doi.org/10.1159/000091198

5. Akbağ M, Sayıner B, Sözen D. An investigation on the relationship between the stress level, control focus and depression level in university students. Atatürk Education Faculty Journal of Educational Sciences. 2005;21:59-74.

6. Şahin NH, Durak A. Coping styles with stress scale: Adaptation for university students. Turkish Journal of Psychology. 1995:10(34):5673.

7. Karaca A, Yıldııım N, Ankaralı H, Açıkgöz F, Akkuş D. Turkish adaptation of perceived stress scale, bio-psycho-social response, and coping behaviours of stress scales for nursing students. Journal of Psychiatric Nursing. 2015;6(1):15-25. https://doi.org/10.5505/phd.2015.40316

8. Cloninger CR, Svrakic DM, Przybeck TR. A psychobiological model of temperamentandcharacter. Arch Gen Psychiatry. 1993:50:97590.

https://doi.org/10.1001/archpsyc.1993.01820240059008

9. Cloninger CR, Przybeck TR, Svrakic DM, Wetzel RD. The temperament and character inventory ( $\mathrm{TCl}$ ): A guide to its development and use. St. Louis, Missouri: Center for Psychobiology of Personality, Washington University; 1994. Available from: https:// www.researchgate.net/profile/Robert_Cloninger/ publication/264329741_TCl-Guide_to_Its_Development_and Use/links/53d8ec870cf2e38c6331c2ee/TCI-Guide-to-ItsDevelopment-and-Use.pdf

10. Schüssler G, Geishauser E, Rüger U. Psychosomatic factors in idiopathic sudden deafness. HNO. 1992;40(1):4-9.

11. An H, Guo M, Han X, Bu G. Analysis of personality characteristics of sudden deafness patients. Lin Chung Er Bi Yan Hou Tou Jing Wai Ke Za Zhi. 2014;28(7):484-6.

12. Lamparter U. Psychosomatic aspects of sudden deafness. Versicherungsmedizin. 1998;50(3):104-9.

13. Lopez-Gonzalez MA, Lopez-Lorenteb C, Abrantea A, Benaixaa P, Estebana F. Sudden deafness caused by lifestyle stress: Pathophysiological mechanisms and new therapeutic perspectives. The Open Otorhinolaryngology Journal. 2009;3:1-4. https://doi.org/10.2174/18744281003010001

14. Schmitt C, Patak M, Kröner-Herwig B. Stress and the onset of sudden hearing loss and tinnitus. Int Tinnitus J. 2000;6(1):41-9.

15. Edizer DT, Çelebi Ö, Hamit B, Baki A, Yiğit O. Recovery of idiopathic sudden sensorineural hearing loss. J Int Adv Otol. 2015;11(2):122-6 https://doi.org/10.5152/iao.2015.1227

16. Neuser J, Knoop T. Sudde nidiopathic hearing loss: Psychopathology and antecedent stressful life-events. $\mathrm{Br} J$ Med Psychol. 1986;59(3):245-51.

https://doi.org/10.1111/j.2044-8341.1986.tb02690.x

17. Yamasoba T, Kikuchi S, Higo R, O'Uchi T, Tokumaru A. Sudden sensorineural hearing loss associated with slow blood flow of the vertebrobasilar system. Ann Otol Rhinol Laryngol. 1993;102(11):873-7. https://doi.org/10.1177/000348949310201110

18. Suckfüll M. Fibrinogen and LDL apheresis in treatment of sudden hearing loss: A randomised multicentretrial. Lancet. 2002;360:1811-7. https://doi.org/10.1016/S0140-6736(02)11768-5

19. Chau JK, Lin JR, Atashband S, Irvine RA, Westerberg BD. Systematic review of the evidence for the etiology of adult sudden sensori neural hearing loss. Laryngoscope. 2010;120:1011-21. https://doi.org/10.1002/lary.20873

20. Hayashi N, Someva N, Endo MY, Miura A, Fukuba Y. Vasoconstriction and blood flow responses in visceral arteries to mental task in humans. Exp Physiol. 2006;91(1):215-20. https://doi.org/10.1113/expphysiol.2005.031971

21. Von Känel R, Mills PJ, Fainman C, Dimsdale JE. Effects of psychological stress and psychiatric disorders on blood coagulation and fibrinolysis: A biobehavioral pathway to coronary artery disease? Psychosom Med. 2001;63:531-44. https://doi.org/10.1097/00006842-200107000-00003

22. Arslan H, Arkar H, Danaoğlu Z. Temperament and character dimensions and levels of anger, anxiety, and depression in persons with myocardial infarction. J Clin Psy. 2011;14(3):143-9.

23. Yazıcı Güleç M. Temperament and character in psychosomatic disorders. Currrent Approaches in Psychiatry 2009;1:201-14.

24. Wallhäusser-Franke E, D'Amelio R, Glauner A, et al. Transition from acute to chronic tinnitus: Predictors for the development of chronic distressing tinnitus. Front Neurol. 2017;8:605. https://doi.org/10.3389/fneur.2017.00605

25. Akvardar Y, Arkar H, Akdede BB, Gül S, Sarı Ö, Tunca Z. Personality features of patients with alcohol use disorders. Journal of Dependence. 2005;6(2):54-60.

26. Childs $\mathrm{E}$, White TL, Wit H. Personality traits modulate emotional and physiological responses to stres. Behav Pharmacol. 2014:25(506):493-502. https://doi.org/10.1097/FBP.0000000000000064 